\title{
RePresentation of Women on CoRporate BOARDS AND INFLUENTIAL COMMITTEES
}

\author{
Tom Wilson
}

Tom Wilson (tw@louisiana.edu) is Professor of Accounting, Moody College of Business Administration, University of Louisiana at Lafayette, P.O. Box 43658, Lafayette, LA 70504.

\begin{abstract}
The lack of women serving as directors on the boards of U.S. corporations has been a topic of concern for many years. Although progress has been made, women still occupy less than $25 \%$ of the board seats of S\&P 500 companies. One reason given for the slow pace of change is that women serving on boards do not exercise real influence over corporate policy because they are not a part of the truly important committees of the board of directors. This study examines the extent to which women serve on, and chair, the audit, compensation, nominating, and executive committees of the board - the so-called "power" committees. Analysis reveals that, particularly among smaller firms, women directors do not have influence because they do not exist. Almost half of the smaller firms in the sample had no independent women directors on their boards. Where women directors do exist, there is a greater than even chance that they do serve on one of the influential committees, although the chance of them being chair is generally
\end{abstract}


less than $30 \%$. A comparison with boards of 10 years ago reveal a slight increase in the influence of women directors. However, these results should be interpreted with care. For example, the finding that over $70 \%$ of firms with at least one woman director on their board named that woman to their nominating committee may give the impression of significant strides toward influence and power. That impression is lessened when the $100 \%$ of nominating committees with more than one male member is considered. When the still significant percentage of firms with entirely male boards is factored in, in far too many cases even a seat at the table would be a considerable improvement for women.

Keywords: gender diversity, corporate governance, directors

DOI: http://dx.doi.org/10.15239/j.brcacadjb.2019.09.01.ja04

\section{INTRODUCTION}

The lack of women serving as directors on corporate boards has often been observed (e.g., Chizema, Kamuriwo \& Shinozawa, 2015; Grosvold, Rayton, \& Brammer, 2015). In the United States, although progress has been made in recent years, women still occupy less than $25 \%$ of the board seats of S\&P 500 companies (Catalyst 2016).

This imbalance persists despite increasing evidence of the benefits to firms of board gender diversity. For example, Kim \& Starks (2016) found that women directors possess unique skills that enhance the overall expertise of boards, increasing their effectiveness. Isidro \& Sobral (2013) examined a large sample of European firms and found that women directors positively affected firm financial performance, as well as compliance with firm ethical and social standards. Post \& Byron (2015) conducted a meta-analysis of 140 studies and found a positive relation between women on the board and accounting returns. Another metaanalysis of 87 studies by Byron \& Post (2016) found a link between female board membership and increased corporate social responsibility. With the benefits of board gender diversity supported by an ever-increasing 
body of research, the continued lack of women directors is an issue meriting further study.

One possible explanation is suggested by Whitler \& Henretta (2018), who argue that gender diversity on company boards has been hampered by the lack of influence of those women who do serve as directors. They note (p. 79):

Our research has led us to believe that the reason women aren't making more rapid inroads is that few have reached the most influential board leadership positions. Although more women are on boards now than 10 years ago, very few have been promoted to a post that would give them influence beyond their seat at the table.

Whitler \& Henretta (2018) argue that this lack of influence stems from a shortage of women serving on what are termed the "power committees" of the board. Prior research has emphasized the importance of this issue. For example, Triana, Miller, \& Trzebiatowski (2014) note that membership on important board committees determines a director's influence on the firm. As Peterson \& Philpot (2007, p. 178) explain:

Most corporate policy originates in meetings of board committees .... Committees, in doing their work, meet separately and make recommendations for approval by the full board. Thus meaningful policy input comes most frequently from the relevant committees' members, rather than from board members who are not on the committee....

Is the influence of women directors limited by their lack of representation on important board committees? This study addresses the question by examining the extent to which woman serve on, and chair, influential board committees. It also extends prior research by incorporating smaller firms into the analysis, rather than focusing exclusively on the largest companies in the United States, such as the S\&P 500. Context is provided by comparison with women board committee membership from 10 years ago. 
The remainder of the paper is divided into three sections. The first section identifies the board committees considered as most influential to a firm. The second section presents the study's research methodology and results. The paper closes with a summary and discussion of the findings.

\section{Influential BoARd Committees}

Whitler \& Henretta (2018) argue that not all board committees are equally important. They report an interview with one corporate director who identifies a "hierarchy of power" among board committees. Chief among these are what Chen \& Wu (2016) refer to as the "required" committees the audit, compensation, and nominating/governance committees. Audit committees are mandated by SEC regulations and stock exchange rules to interact with the external auditor and to oversee the financial reporting process. Both the NYSE and NASDAQ exchanges also require firms to have compensation and nominating/governance committees (Chen \& $\mathrm{Wu}$ 2016). Although it may have other functions, the compensation committee has as its chief responsibility the compensation of the firm's top executives. The nominating and corporate governance committee, in addition to being in charge of general governance procedures, is responsible for recommending new candidates for seats on the board.

A fourth influential committee, the executive committee, is not required either by law or regulation. Many firms do not have executive committees, but those that do generally give them considerable power. For example, the executive committee of Textron (2017) "has the power, between meetings of the Board of Directors, to exercise all of the powers of the full Board ...."

These four committees have often been identified in prior research as the most powerful on the board of directors. Whitler \& Henretta (2018) and Triana, Miller, \& Trzebiatowski (2014) both classify the audit, compensation, and nominating and governance committees as influential. 
Triana, Miller, \& Trzebiatowski (2014) and Dalton \& Dalton (2010) also name the executive committee as one of the most powerful on the board.

Another indicator of the influence of women directors is the degree to which they chair the power committees, rather than simply serving as members. Whitler \& Henretta (2018, p. 80) emphasize the importance of women chairing committees, as opposed to merely serving on them:

Leaders of committees set the agenda for decision-making and therefore wield more power than other directors. In the committees generally acknowledged to involve heavier lifting - especially audit, nominating/governance, and compensation - their power can meaningfully change the course of events. They have builtin influence over important board decisions such as who the next CEO will be, who comprises the slate of future board members, how executive compensation is structured, and more.

Joy (2008, p. 19) echoes this point, noting that the chairs of the audit, compensation, and nominating committees have the power to set agendas, allocate resources, and orchestrate decision making. Chairs of these committees are "among the most powerful and influential board leaders."

\section{Methodology and Results}

To ensure a broad cross-section of firms in the sample, companies were selected from two sources. First, 100 firms were randomly selected from the S\&P 500 Index. Another random sample of 100 companies was then drawn from the Russell Microcap Index, which consists of 2,000 of the smallest publicly held firms in the country. The resulting sample of 200 companies thus represents both the largest and smallest public firms in the United States.

For each sample firm, proxy statements filed with the SEC in 2017 were examined to determine the representation of women on influential board committees. Since the audit, compensation, and nominating committees 


\section{The BRC Academy Journal of Business Vol. 9, No. 1}

are required by exchange rules to have only independent directors, the focus of this analysis is on independent women directors.

Not all firms used the same committee structure or terminology. For example, some firms combined the compensation and nominating and governance functions into one committee. For purposes of this analysis, those committees were classified as compensation committees. Since more firms used the title "nominating committee" than "nominating and governance committee" that terminology is adopted for the remainder of this paper. Also, committees were classified according to function rather than title - any committee responsible for executive compensation, no matter its official title, was classified as a compensation committee. To provide a benchmark with which to assess progress over time, data were also gathered from firm proxy statements filed in 2007. Selected descriptive information about the sample is provided in Table 1.

\section{PREVIEW COMPLETE}

This completes the limited preview of this paper. Please visit the link below to purchase.

\section{Citation Information}

Wilson, Tom. "Representation of Women on Corporate Boards and Influential Committees." The BRC Academy fournal of Business 9, no. 1 (2019): 61-74. http://dx.doi.org/10.15239/j.brcacadjb.2019.09.01.ja04 